\title{
VIRADA GEO(NTO)LÓGICA: REFLEXÕES SOBRE VIDA E NÃO-VIDA NO ANTROPOCENO
}

ALYNE DE CASTRO COSTA

\begin{abstract}
Resumo: Neste texto, apresento 0 conceito de "geontologia" cunhado por Elizabeth Povinelli a partir de seu trabalho com povos indígenas da Austrália e discuto sua importância e contribuição para o pensamento e a ação a respeito da relação entre vida e não-vida, especialmente no contexto da grave catástrofe ecológica que marca nosso tempo.
\end{abstract}

No artigo intitulado "Do rocks listen?" (1995), Elizabeth Povinelli conta sobre sua participação em uma audiência do processo conhecido como Kenbi Land Claim, no qual o povo aborígene Larrakia buscava obter direito de propriedade sobre a Península Cox, no Território Norte da Austrália. Na ocasião, uma das mulheres do povo Belyuen, que habita a área, descrevia aos representantes do governo como uma rocha chamada Old Man Rock, ${ }^{1}$ de grande importância na sua cosmologia, era capaz de ouvir e sentir o suor dos povos aborígenes quando eles passavam ali para a caça ou a coleta, para acampar ou apenas passar o tempo, e falava da importância das interações entre humanos, ambientes e os seres totêmicos ancestrais - os Dreamings - para a saúde e produtividade do campo. ${ }^{2}$

\footnotetext{
${ }^{1}$ Old Man Rock ou Darri-ba Nungalinya é uma rocha sagrada localizada próximo à costa de Nightcliff, na cidade de Darwin, Território do Norte da Austrália. Seu espírito, quando despertado ou perturbado pelas ações dos humanos, causa devastação por meio de tormentas meteorológicas, como tempestades severas e ciclones.

${ }^{2}$ De acordo com a mitologia aborígene australiana, houve um tempo - chamado de Dreaming, Dreamtime ou Dreamtimes (Tjukurrpa) - em que espíritos totêmicos ancestrais passaram pela terra, criando a vida e importantes locais sagrados. Povinelli explica que "[o] Dreaming pode ser entendido como a pré-condição do mundo humano e natural estabelecida no passado ancestral. [...T] oda a matéria (corpos humanos e animais, objetos e ambientes) é concebida como o trabalho cristalizado dos seres do Dreaming ancestrais. Enquanto as ações míticas de alguns ancestrais do Dreamtime foram concentradas em certos lugares hoje sagrados, a terra é, de uma forma geral, permeada por sinais de sua agência e
} 
Certamente, diz Povinelli, o comissário do governo australiano que presidia a audiência não acreditava que os Dreamings pudessem ouvir, perceber, agir ou reagir intencionalmente à presença dos humanos. Seu trabalho ali era avaliar a autenticidade cultural daquilo que era expressado por aquela integrante do povo Belyuen, com vistas a informar a decisão sobre a demarcação do território; tal avaliação, no entanto, se dava sem que ele próprio "interroga[sse] criticamente as crenças culturais que subjazem e organizam seu próprio esquema avaliativo". ${ }^{3}$ Isso se dá, prossegue a autora, porque as estruturas culturais que baseiam a economia política foram há tempos - podemos acrescentar, ao menos desde a modernidade - transformadas em fatos neutros e objetivos: "as crenças podem fazer parte da sociedade e da cultura, mas o trabalho, a ecologia e o valor econômico se referem a condições materiais que são tratadas de forma mais precisa por meio do paradigma científico". ${ }^{4}$ Assim, por mais que o tratamento dado pelos governos aos direitos das minorias étnicas tenha, ao longo do tempo, incorporado aspectos que supostamente demonstram respeito e valorização da cultura dita tradicional, seu sistema avaliativo foi muito pouco influenciado pela compreensão desses povos sobre as relações entre humanos e ambiente: ele é guiado pelas "noções ocidentais de produção, valor, lazer e trabalho, seus sujeitos e objetos e o deslocamento da objetividade do domínio cultural para o econômico-ecológico". ${ }^{5}$

Na raiz dessa "organização cultural da descrença ocidental" ${ }^{\text {"6 }}$ que desqualifica outras visões de mundo, cosmologias ou ontologias por aspirar à pretensa univocidade de uma certa ordem física e metafísica das coisas (a sua própria), encontra-se, afirma Povinelli em trabalhos mais recentes, uma certa concepção ontológica fundamentada em um tipo específico de ser: "o ser vivo e, mais

intencionalidade presentes ainda hoje. Assim, por exemplo, na região em que eu trabalho, certos poços d'água foram formados pelas viagens do Dreaming Dingo, que se movia debaixo da terra, emergindo em certos lugares para executar determinados feitos. Em todos os lugares em que ele emergiu, deixou um poço d'água. Esses poços não apenas marcam o que aconteceu no passado, eles também mostram onde Dingo permanece hoje" (1995, p. 509).

${ }^{3}$ POVINELLI, E. "Do rocks listen?", p. 505. Todas as citações a esta autora no presente trabalho são traduções minhas.

4 POVINELLI, E. “Do rocks listen?”, p. 505.

5 POVINELLI, E. “Do rocks listen?”, p. 506; 515.

6 POVINELLI, E. “Do rocks listen?”, p. 506. 
especificamente, o ser que extrai sua diferença da diferença absoluta entre seres vivos e não-vivos".7 A autora chama de "imaginário do carbono" o conjunto de processos metabólicos - quais sejam, nascimento, crescimento/reprodução e morte - que a epistemologia ocidental atribui à vida biológica e que serve como marcador da diferença entre vida e não-vida. Com efeito, esse imaginário cria a pressuposição de que há uma separação abissal entre o orgânico e $\circ$ inorgânico, desconsiderando como mera matéria inerte desprovida de agência e intencionalidade os modos de existência que não parecem passar por esses processos metabólicos.

Por essa razão, ela postula que o que tradicionalmente vem sendo chamado de "ontologia" no Ocidente é, de fato, uma "biontologia". Nesse sentido, a autora, expandindo o conceito cunhado por Michel Foucault, afirma que a biopolíitica não é apenas aquilo que busca governar sobre a vida, mas sim o que cria e mantém a divisão entre vida e não-vida, a qual é essencial tanto para a governança das diferenças por parte dos Estados liberais -entenda-se, 0 controle e a regulação da relação com determinados grupos marginalizados socialmente, incluindo os povos de cosmovisões não-ocidentais - quanto para a contínua geração de riquezas econômicas baseadas na extração, manipulação e transformação de elementos minerais em produtos industrializados. $O$ leitmotiv do metabolismo, assim, perpassa incólume as ciências naturais, sociais e humanas, a teoria crítica, a governança estatal e os mercados de capital. Em suas palavras,

[d]esde sua inauguração como um campo de reflexão filosófica, a ontologia tem sido definida por meio de problemas de ser e não-ser, finitude e infinitude, o zero e o (múltiplo) um, muitos dos quais criam e pressupõem um tipo específico de entidadeestado, a saber, a vida. Nas ciências naturais, sociais e filosóficas, a "vida" age como uma divisão fundacional entre entidades que têm a capacidade de nascer, crescer, se reproduzir e morrer, e aquelas que não têm: biologia e geologia, bioquímica e geoquímica, vida e não-vida. A ontologia é, então, estritamente falando, uma "biontologia". Seu poder é a habilidade de transformar um plano de existência regional - basicamente, os entendimentos ocidentais sobre

7 POVINELLI, E. “Geontologies: Being, Life, and Endurance in Late Liberalism”, manuscrito. 
quais entidades têm essas capacidades - em um arranjo global. $^{8}$

Em oposição a essa biontologia e à biopolítica que a sustenta, a autora propõe - conceito de geontologia, que consiste na abertura a outras concepções de mundo que não sejam marcadas pela dualidade entre vida e não-vida (ou pelas distinções ontológicas no próprio âmbito da vida, como a entre humanos e animais ou entre animais e plantas), e que concedam dignidade ontológica, por assim dizer, à geologia e demais seres não-orgânicos. ${ }^{9}$ Povinelli afirma que se, durante os últimos séculos, os Estados e o capital liberais se viram beneficiados pela formação de poder biontológico, a grave desordem ecológica da atualidade - que, muitos cientistas propõem, acarretou a entrada do planeta no Antropoceno, a nova época geológica na qual o planeta passa a exibir as marcas do impacto da ação humana sobre sua superfície - propiciou a emergência da geontologia como nova formação de poder capaz de desabilitar o imaginário do carbono. Isso porque, se, no Antropoceno, constatamos a contundente falência do "sistema de coordenadas moderno" ${ }^{10}$ que organizava 0 mundo conforme os domínios da natureza e da cultura e (outras dicotomias análogas, como as entre sujeito e objeto e entre agente e ambiente); ou, dito de outro modo, se a crise ecológica desencadeou uma crise epistemológica e civilizacional, denunciando que a ontologia moderna, longe de constituir uma universalidade organizativa, apresenta(va) apenas um mundo (ainda que muito poderoso) entre muitos, o Antropoceno invoca a necessidade de abrirmos espaço para novas concepções e teorias de conhecimento em que vida e nãovida não sejam os operadores-padrão de distinção ontológica (e nem que tal distinção continue acarretando a desqualificação de outros povos e de outros conhecimentos como "primitivos" ou "irracionais").

\footnotetext{
${ }^{8}$ POVINELLI, E. "Interview with Elizabeth Povinelli by Mat Coleman and Kathryn Yusoff”. In: Society \& Space [online].

9 " $\mathrm{E}$ contudo, para meus colegas indígenas, como era para seus pais e avós, determinadas rochas realmente escutam, e cheiram, e interpretam os fatos correntes [...]. Mais precisamente, um mundo geológico animado é a condição de outras formas de vida e a medida de seus valores éticos e sociais" (POVINELLI, E. "Geontologies: Being, Life, and Endurance in Late Liberalism", manuscrito, grifo meu). ${ }^{10}$ Para usar a expressão de Bruno Latour em Nous n'avons jamais étés modernes: Essai d'anthropologie symétrique (Paris: La Découverte, 1991).
} 
A autora declara que seu interesse é empreender uma antropologia do diferinte $^{11}$ [otherwise] ontologicamente informada: segundo essa proposta, a ontologia constitui um certo arranjo dos existentes no plano de existência, sendo que tanto os arranjos são imanentes ao plano de existência quanto o plano de existência também é imanente em relação a si mesmo e às entidades que nele se encontram. Assim, no arranjo dos existentes no plano de existência, entes humanos e não-humanos criam conjuntamente um lar para seus ocupantes; é a vinculação entre eles que mantém o conjunto existindo sob uma determinada forma. Ocorre, portanto, uma constituição mútua do mundo, um processo geontológico de "devir junto"; e daí decorre a impossibilidade - que marca as geontologias aborígenes, assim como outras não-modernas - de separar vida e não-vida, biologia e geologia.

Porém, todo arranjo traz consigo seus próprios possíveis desarranjos e rearranjos - o diferinte. Podemos dizer, assim, que o diferinte é a condição mesma de possibilidade de alteração dos arranjos de existência, imanente a esses arranjos. A tarefa ético-política que se coloca na antropo-ontologia do Antropoceno, desse modo, é evidenciar as diversas geontologias que vêm sendo subjugadas pela pretensa universalidade da biontologia ocidental, empreendendo uma espécie de ativação dos diferintes que persistem nos arranjos de existência baseados na distinção entre vida e não-vida. Os muitos nomes do diferinte ganham vida, assim, conforme conseguem provocar desarranjos e novos rearranjos nas combinações de existentes-na-existência atuais - afinal, não podemos efetivamente chamar de desarranjo o abalo provocado, por exemplo, pela mudança climática nas composições rigidamente bipolarizadas que herdamos da modernidade?

Como então pensar e estabelecer um lugar para os seres na geontologia? Pensemos no exemplo dado por Povinelli sobre Tijpel. Para os indígenas Karrabing, Tiipel era uma jovem que, mesmo tendo escondido seus seios e se feito passar por menino, foi estuprada por um homem velho e se tornou uma

\footnotetext{
${ }^{11}$ Sugestão de tradução proposta por Eduardo Viveiros de Castro, Déborah Danowski e Juliana Fausto a propósito da entrevista realizada por ocasião do Colóquio Internacional Os Mil Nomes de Gaia - Do Antropoceno à Idade da Terra, 2014.
} 
enseada da ilha Norfolk, que fica entre a Austrália, a Nova Zelândia e a Nova Caledônia. Ora, no imaginário do carbono, Tijpel não pode ser considerada uma forma de vida: ela é mineral, geológica; "e, como tal, ela pode se tornar uma mina que pode ser exaurida, mas não morta". ${ }^{12}$ Conseguiremos então, na geontologia que emerge no Antropoceno, estabelecer uma teoria sobre o ser em que a forma de vida representada por Tijpel encontre um lugar? Um imaginário em que os seres geológicos não tenham vida apenas metaforicamente, no âmbito das representações culturais? Sentiremo-nos obrigados a preservar os arranjos que mantêm Tijpel na existência, da mesma forma como desejamos preservar a vida humana diante da catástrofe ambiental? ${ }^{13}$ "Como a não-vida vai entrar no demos? Vamos deixá-los falar como deixamos os povos indígenas falarem?", ela pergunta. ${ }^{14}$

Talvez a noção de "vida" na geontologia possa ser melhor compreendida por meio da definição oferecida por Georges Canguilhem, segundo a qual é próprio da vida empreender "um esforço espontâneo [...] para lutar contra aquilo que constitui um obstáculo à sua manutenção e a seu desenvolvimento tomados como normas". ${ }^{15}$ Canguilhem, portanto, desloca o entendimento da vida do domínio das definições abstratas e universalistas para uma dimensão performativa; ${ }^{16}$ se pudermos ampliar a definição que ele fornece para além dos domínios biológicos, talvez possamos compreender como dotadas de certa forma de vida todas as entidades capazes de empreender esforço para persistir em uma existência que está em constante mutação.

Pensar a vida fora das imposições biológicas também implica mudar o olhar sobre a morte, especialmente sobre a morte humana ou mesmo sua extinção, temor que - não sem razão - vem ganhando espaço no imaginário contemporâneo diante da constatação da atual desordem ambiental planetária.

\footnotetext{
${ }^{12}$ POVINELLI, E. Entrevista concedida por ocasião do Colóquio Internacional Os Mil Nomes de Gaia: Do Antropoceno à Idade da Terra.

13 POVINELLI, E. "Geontologies: A Requiem to Late Liberalism".

${ }^{14}$ POVINELLI, E. Entrevista concedida por ocasião do Colóquio Internacional Os Mil Nomes de Gaia: Do Antropoceno à Idade da Terra.

${ }^{15}$ CANGUILHEM, G. O Normal e o Patológico, p. 48.

${ }^{16}$ Apesar dessa definição, aponta Povinelli, o próprio autor não transpõe tal entendimento para além da biologia, o que reforça o abismo estabelecido entre bios e geos.
} 
Não sem causar algum desconforto, Povinelli afirma ser preciso "desdramatizar o humano", sua morte e extinção. Tal afirmação, no entanto, não consiste em uma tentativa de amenizar a catástrofe ecológica e seus efeitos; ela problematiza a própria elaboração social da catástrofe, sua "eventização", sua fixação como um acontecimento extraordinário para onde nossos olhares devem se voltar - enquanto negligenciamos os pequenos acontecimentos de "morte lenta", as experiências cotidianas de deterioração a que todos os seres estão submetidos sob a ordem do sistema político e econômico neoliberal. Nesse sentido, podemos inferir de tal afirmação que a mobilização (mesmo que ainda impressionantemente discreta) em torno da desordem ecológica e dos riscos que ela representa à humanidade enquanto espécie (ou às outras formas de vida orgânica) cria uma espécie de cena para (melo)dramatizar a extinção: concentramo-nos na iminência de um grande evento, enquanto nosso dia-a-dia é repleto de flagrantes situações de sofrimento, precariedade e exaustão, como os extermínios e as condições degradantes a que estão submetidos determinados indivíduos e povos e a deterioração contínua dos seres-da-terra ${ }^{17}$ vistos como meros recursos naturais. ${ }^{18}$

Assim, desdramatizar o humano, a meu ver, possui (ao menos) dois significados. Em primeiro lugar, o mais evidente deles, é que o humano, enquanto forma de vida isolada dos outros existentes, não existe. Por essa razão, se preocupar com o fim da existência humana não tem sentido se não nos angustiarmos também, ou antes, com os processos de exaurimento generalizado de coletivos humanos e outros-que-humanos sobre os quais nossa civilização se erigiu e se mantém. Além disso, sabemos claramente que a

\footnotetext{
${ }^{17}$ Expressão usada por Marisol de la Cadena no artigo "Indigenous Cosmopolitics in the Andes: Conceptual Reflections beyond 'Politics'". In: Cultural Anthropology, vol. 25, no. 2, 2010, p. 334-370.

${ }^{18} \mathrm{O}$ fim do mundo, nesse sentido, como afirmam Déborah Danowski e Eduardo Viveiros de Castro, é "uma espécie de acontecimento fractal, que se reproduz indefinidamente em diferentes escalas, das guerras etnocidas em diversas partes da África ao assassinato sistemático de líderes indígenas ou militantes ambientalistas na Amazônia, da compra de territórios gigantescos de países pobres por potências hiperindustriais à grilagem e desmatamento de terras indígenas por interesses minerários e agronegociais, à expulsão de uma única família de camponeses para a ampliação de um campo de soja transgênica... Isso para não falarmos da 'fractalização' do fim que percorre de cima a baixo a Grande Cadeia do Ser, com a desaparição dos inumeráveis Umwelten [mundos próprios] dos viventes" (DANOWSKI, D; VIVEIROS DE CASTRO, E. Há mundo por vir? Ensaio sobre os medos e os fins, p. 139).
} 
extinção que preocupa, em muitos casos, não é a de todos os humanos, tendo em vista a tolerância, indiferença e até naturalidade com que muitas vezes o genocídio de grupos marginalizados é tratado. Nesse sentido, é preciso reconhecer que a extinção que tanto nos assusta enquanto "evento catastrófico" se manifesta há tempos como uma degradação progressiva de inúmeros seres e comunidades de seres; ela é a condição mesma de manutenção do mundo em que vivemos. Tal perspectiva, assim, pode suscitar outras abordagens éticas e políticas - decerto localizadas, sem pretensões de abarcar todo o problema, mas passíveis de serem colocadas em prática e de se articularem umas às outras -, ações de resistência e combate aos episódios de morte lenta de causa neoliberal que, por se acumularem quase desapercebidamente ao longos dos séculos, causam a impressão de que a catástrofe ainda está por vir.

E, em segundo lugar, desdramatizar o humano remete à dissolução da fronteira entre (ou mistura entre os domínios da) vida e não-vida de que vimos tratando ao longo deste trabalho: se a "morte lenta" é já uma morte em vida - na qual os seres a ela submetidos lutam para sobreviver, adaptando-se e transformando-se conforme as condições de existência, sem necessariamente chegar a se esvair -, o Antropoceno talvez não signifique a extinção completa: no caso dos humanos, é provável que nos tornemos, junto com a Terra, outros, ou mais precisamente, diferintes. Isso não significa, no entanto, que devemos gostar daquilo que vamos nos tornar; quer dizer apenas que tal transformação já começou a acontecer, e ganha espaço gradativamente, de certa forma com a nossa anuência - pois o que precisaria ser feito para impedir as mortes/transformações lentas que se acumulam diariamente não parece estar em vias de acontecer. ${ }^{19}$

Meu interesse na obra de Elizabeth Povinelli se deve a uma profunda inquietação, que me acompanha já há alguns anos, sobre o que pensar e fazer

\footnotetext{
19 "Portanto, por um lado, se quisermos minerar o planeta inteiro e quisermos [...] falar pelo Skype e voar para cima e para baixo o tempo todo, nós podemos fazer isso; mas nós, com a Terra, nos tornaremos diferintes. E se, em vez de sair correndo por aí, nós encararmos isso calmamente, e dissermos "certo, vamos nos tornar diferintes, nos tornaremos cheios de muco e asmáticos e certamente muito diferentes neurológica e reprodutivamente" - está bem. Se não quisermos fazer isso, então há coisas bem dramáticas que precisamos fazer, e não acho que vamos fazer" (POVINELLI, E. Entrevista concedida por ocasião do Colóquio Internacional Os Mil Nomes de Gaia: Do Antropoceno à Idade da Terra).
} 
a respeito da crise ecológica que já devasta nossas condições materiais e emocionais de existência - esse "nossa" abarcando toda a comunidade de seres, sejam eles humanos, biológicos ou geontológicos. Se refletir sobre o tipo de ação política que está à altura da gravidade dessa crise já constitui uma tarefa absolutamente desafiadora, mais difícil ainda, me parece, é fazê-lo sem resvalar (mesmo com a melhor das intenções) em práticas renovadas de colonialismo - entenda-se, fundamentar nossa ação em uma ontologia que, organizada conforme bipolaridades restritas (seja a oposição entre natureza e cultura, seja a entre vida e não-vida) e se auto-pressupondo universal, destitui o valor de outros modos de existência, tanto de humanos - como nos casos de violência e subjugação dos povos não-ocidentais pelos modernos - quanto de outros-que-humanos (refiro-me aqui à costumeira concepção destes como meros recursos a serem utilizados, manipulados e, finalmente, descartados pelos humanos, seja por meio da transformação antrópica de biomas, seja através da ofensiva colonizadora contra os animais).

Essa política capaz de tratar dos assuntos comuns a distintos coletivos sem aderir a práticas de dominação colonial pode ser melhor descrita pela proposta que Isabelle Stengers chama de "cosmopolítica", a capacidade de "suspender os hábitos que nos fazem acreditar que sabemos o que sabemos e quem somos, que possuímos o sentido daquilo que nos faz existir". ${ }^{20}$ Maus hábitos, de fato, que nos fazem "transformar um tipo de prática da qual somos particularmente orgulhosos em uma chave neutra universal válida para todos" ${ }^{21}$ Se pudermos suspender as categorias supostamente universais que alimentam a biontologia ocidental ao nos confrontar diretamente com os outros seres com quem, e não sobre quem, devemos decidir, o que decidiremos? Seremos capazes de intervir nos processos de morte lenta cotidianos engendrados pelo capital liberal? Seremos capazes de tornar efetivamente difícil, escandalosa ou mesmo inaceitável a decisão de extrair e comercializar minérios, queimar combustíveis fósseis, exaurir a terra, explorar animais, devastar paisagens?

\footnotetext{
${ }^{20}$ STENGERS, I. "The cosmopolitical proposal", p. 14.

${ }^{21}$ STENGERS, I. "Reclaiming animism".
} 
Nesse sentido, a obra de Povinelli inspira novas reflexões e abordagens da questão ecológica sob uma perspectiva cosmopolítica orientada por uma postura descolonizadora. Se, como afirma Povinelli, a crise ecológica, assim como a mudança climática e as cosmopolíticas indígenas, são alguns dos muitos nomes dos diferintes, talvez seja possível a nós criar novas maneiras de, a exemplo do que os índios Karrabing amigos da autora vêm fazendo, aprender a constituir o mundo que estamos herdando. 
Bibliografia

CANGUILHEM, G. O Normal e o Patológico. 6a edição / 2a reimpressão. Rio de Janeiro, São Paulo: Editora Forense Universitária, 2009.

DANOWSKI, D.; VIVEIROS DE CASTRO, E. Há mundo por vir? Ensaio sobre os medos e os fins. Desterro [Florianópolis]: Cultura e Barbárie; Instituto Socioambiental, 2014.

POVINELLI, E. "Do rocks listen?" In: American Anthropologist. New Series, Vol. XCVII, № 3 (1995), p. 505-518.

- "Geontologies: A Requiem to Late Liberalism". Palestra proferida no evento The Anthropocene Project. An Opening, realizado na Haus der Kulturen der Welt, Berlim, Alemanha, 2013. Disponível em: $<$ https://www.youtube.com/watch? $v=W 6 T L l g T g 3 L Q>$. Último acesso em: 17 fev. 2016.

. "Geontologies: Being, Life, and Endurance in Late Liberalism". Manuscrito da comunicação apresentada no colóquio Métaphysiques comparés: La philosophie à l'épreuve de l'anthropologie, realizado no Centre Culturel International de Cerisy, 2013.

. Interview with Elizabeth Povinelli by Mat Coleman and Kathryn Yusoff. In:

Society \& Space [online]. 2014. Disponível em: $<$ http://societyandspace.com/material/interviews/inter

view-with-elizabeth-povinelli-by-mat-coleman-and-kathryn-yusoff/>. Último acesso em: 17 fev. 2016.

- Entrevista concedida por ocasião do Colóquio Internacional Os Mil Nomes de Gaia: Do Antropoceno à Idade da Terra, realizado no Rio de Janeiro, 2014. Disponível em: <http://osmilnomesdegaia.eco.br/videos/>. Último acesso em: 17 fev. 2016.

STENGERS, I. "The cosmopolitical proposal". 2004. Disponível em: $<$ http://mnissen.psy.ku.

dk/Undervisning/Stengers05.pdf > Último acesso em: 17 fev. 2016.

"Reclaiming animism". In: E-Flux [online]. N. 36, jul. 2012. Disponível em: <http://www.e-flux.com/journal/reclaiming-animism/>. Último acesso em: 17 fev. 2016. 